http://jmscr.igmpublication.org/home/ ISSN (e)-2347-176x ISSN (p) 2455-0450 crossref DOI: https://dx.doi.org/10.18535/jmscr/v8i3.114

\title{
To Study the Prevalence of Occult HBV Infection \& Reactivation of HBV in Hematological Cancer Patients on \& Before Cancer Chemotherapy
}

\author{
Authors \\ G N Gireesh ${ }^{1}$, A R Venkateshwaran ${ }^{2}$, K Premkumar $^{3}$, R Murali $^{4}$, P Arun $^{5}$ \\ Institute of Medical Gastroenterology, Madras Medical College and Rajiv Gandhi Government General \\ Hospital, Park Town, Chennai 600003, Tamil Nadu \\ ${ }^{1}$ Senior Resident, Institute of Medical Gastroenterology, Madras Medical College Chennai \\ ${ }^{2}$ Director and Head of Department, Institute of Medical Gastroenterology, Madras Medical College Chennai \\ ${ }^{3}$ Associate Professor, Institute of Medical Gastroenterology, Madras Medical College Chennai \\ ${ }^{4}$ Assistant Professor, Institute of Medical Gastroenterology, Madras Medical College Chennai \\ ${ }^{5}$ Senior Resident, Institute of Medical Gastroenterology, Madras Medical College Chennai \\ *Corresponding Author
}

\section{A R Venkateshwaran}

\begin{abstract}
Background: Occult hepatitis B infection is defined by negative hepatitis B surface antigen (HBsAg) and detectable hepatitis $B$ virus (HBV DNA, with or without hepatitis B core antibody (anti-HBc). HBV reactivation is most commonly reported in patients receiving cancer chemotherapy for haematological malignancies or hematopoietic stem cell transplantation (HSCT) recipients.

Objective: In this study, we aimed to determine the prevalence \& reactivation of occult HBV infection in hematological cancer patients on \& before receiving chemotherapy.

Methods: The study was conducted in patients admitted in hematology department RGGGH, Madras medical college, Chennai for a time period from September 2018 to December 2018.Blood samples collected from newly diagnosed hematological malignancy and patients with diagnosed hematological malignancy on chemotherapy who were previously negative for HBsAg, were tested for HBsAg \& anti$H B c$ antibodies. The samples that were negative for HBsAg but positive for anti-HBc also examined for $H B V$-DNA by polymerase chain reaction (PCR).

Results: Out of the 80 patients tested, 23 (28\%) samples were positive for anti-HBc antibodies. HBV-DNA was detected in 5(6\%) of anti-HBc positive samples. Reactivation of HBV occurred in $11 \%$ of patients. Reactivation was more frequent with chemotherapy drugs like Rituximab \& daunorubicin. There was no significant difference in $H B c$ antibody positivity based on gender, age, previous blood transfusions, biochemical parameters $(A L T)(P>0.05)$.

Conclusion: The prevalence of occult $H B V$ infection is $6 \%$ with isolated anti $H B C$ positivity being $28 \%$. Reactivation of $H B V$ was seen in 9 patients (11\%) Screening of occult $H B V$ infection by $H B s A g, H B V$ DNA and anti HB core antibody should be made mandatory before starting patients on immunosuppressants in cancer patients.
\end{abstract}




\section{Introduction}

Hepatitis B virus (HBV) infection is a serious health problem in the world with nearly two billion people affected ${ }^{1}$. Implementation of hepatitis B surface antigen (HBsAg) screening in blood donors in the early 1970s has greatly reduced the transmission ${ }^{2}$. The natural history of HBV infection depends upon host factors such as integrity of immune system, age at primary infection, as well as viral factors including HBV genotype, viral mutations and viral load ${ }^{3}$.

Occult HBV infection (OBI) is normally defined by negative serum hepatitis $B$ surface antigen (HBsAg) and detectable HBV DNA in the liver and/or serum, with or without hepatitis B core antibody (anti-HBc) $)^{4}$. Several studies shows the risk of flaring up of chronic Hepatitis B (positive $\mathrm{HbSAg}$ ) in patients treated by chemotherapy for hematologic and solid malignancies, with the highest risk of flare occurring when chemotherapy is discontinued. In these studies, the risk of reactivation of Hepatitis B is between $20 \%$ and $50 \%{ }^{5-7}$. The diagnosis of OBI is difficult due to the presence of low amounts of viral DNA $(<200$ $\mathrm{IU} / \mathrm{mL})$ in the infected persons without detectable $\mathrm{HBsAg}^{(8)}$. The individuals with an OBI undergoing immunosuppression are generally at risk of HBV reactivation.

It is very obvious that the clinical \&virological reactivation of occult $\mathrm{HBV}$ infection has been frequently revealed in various clinical settings, such as HIV infection, hematologic cancer, hematopoietic stem cell, and organ transplantation $^{(4,9)}$. In these situations, the mortality rate in HBV reactivation is close to 20 percent, because of the liver failure or the development of the primary disease $\mathrm{e}^{(10,11)}$.

Hence, the aim of this study was to evaluate the prevalence and chemotherapy induced reactivation of OBI among hepatitis B surface antigen negative patients with hematological malignancies and to establish the significance of core antibody screening among this group of patients before receiving chemotherapy.

\section{Methods}

The study was conducted in patients admitted in hematology department RGGGH, Madras medical college, Chennai for a time period from September 2018 to December 2018.Newly diagnosed hematological malignancy and patients with diagnosed hematological malignancy on chemotherapy were included. All individuals were asked regarding age, sex, type of cancers, blood transfusion, jaundice and history of hepatitis B vaccination. Venous samples were tested for hepatitis B core antibody $\mathrm{HBcAb}$ and $\mathrm{HBsAg}$ using a commercially available enzyme-linked immunosorbent assay. HBV DNA was done for those patients with isolated $\mathrm{HBcAb}$ positivity and those who developed reactivation of $\mathrm{HBV}$ on treatment.

Patients with recent jaundice, recent hospitalization due to fever, recent delivery less than 12 weeks or close contact with a patient suffering from hepatitis in the last 6 months were excluded. Exclusion criteria also included acute or chronic HBV infection as marked by positive HBsAg and patients with HCV, human immunodeficiency virus (HIV) were excluded.

Before start of the cancer therapy each patient underwent history taking, complete physical examination, routine biochemistry assays including alanine transaminase (ALT), aspartate transaminase (AST), total and direct bilirubin. Patients with HBV infection as labeled by positive HBsAg were excluded.

Venous blood samples for occult hepatitis B infection (OBI) were obtained from all patients for $\mathrm{HBsAg}$, antiHBc antibody. Samples were tested for hepatitis B core antibody ( $\mathrm{HBcAb}$ ) and HBsAg using a commercially available enzymelinked immunosorbent assay. In patients positive for anti $\mathrm{HBc}$ antibody, HBV DNA was performed using PCR.

Patients who were $\mathrm{HBsAg}$ negative, $\mathrm{HBc}$ antibody positive and serum HBV DNA positive $(>50$ $\mathrm{IU} / \mathrm{mL}$, according to kit inc) were labelled as occult hepatitis $\mathrm{B}$ infection (OBI). Reactivation was defined when there was evidence of HBsAg 
seroreversion (the reappearance of HBsAg) with an increase in HBV DNA levels when compared with baseline HBV-DNA levels (>2000 IU/mL) in the absence of history, clinical or laboratory features of all other possible etiological factors of hepatitis $^{12}$.

Statistical Analyses- The SPSS software version 16.0 and chi-square test were used for data analysis. The significance level was $P<0.05$.

\section{Results}

There were a total of 80 patients. There were 80 patients included in the study. $47(58 \%)$ male \& $33(41 \%)$ females were included. The mean age group was $40.65 \pm 15.9$. There was no significant difference in $\mathrm{HBc}$ antibody positivity based on age, gender, duration of disease, previous blood transfusions (BT) or biochemical parameters (ALT) levels $(P>0.05)$ (Table 1,2,3,4 \& 5).

High risk medication (like rituximab, daunorubicin) was given to 54(67.6\%) of patients and moderate risk (imatinib) given to to 21 (26.2\%) (Table 6 \& 7). There was higher prevalence of occult $\mathrm{HBV}$ infection in patients who were given high risk medications (statistically not proved)

Of the total 80 patients, isolated anti HBC positivity was seen in 23 patients (28\%). HBV DNA was positive in 5 of 23 patients and negative in 18 patients $(22.5 \%)$. Reactivation of $\mathrm{HBV}$ was seen in 9 patients $(11 \%)$ (Table 8$)$

Table 1: Association between Age with Occult HBV

\begin{tabular}{|l|c|c|c|c|}
\hline Variable & Occult HBV & No Occult HBV & t Test & P Value \\
\hline Age in years (Mean \pm SD) & $46.8 \pm 14.1$ & $38.2 \pm 16.1$ & -2.26 & 0.026 \\
\hline
\end{tabular}

Table 2: Association between Gender with Occult HBV

\begin{tabular}{|l|c|c|c|c|c|}
\hline Gender & $\begin{array}{c}\text { Occult HBV } \\
\mathbf{N}(\%)\end{array}$ & $\begin{array}{c}\text { No Occult HBV } \\
\mathbf{N}(\boldsymbol{\%})\end{array}$ & $\begin{array}{c}\text { Total } \\
\mathbf{N}(\boldsymbol{\%})\end{array}$ & $\begin{array}{c}\text { Chi-square } \\
\text { Test }\end{array}$ & $\begin{array}{c}\mathbf{p} \\
\text { value }\end{array}$ \\
\hline Male & $11(47.8)$ & $36(63.2)$ & $47(58.8)$ & 1.59 & 0.2 \\
\hline Female & $12(52.2)$ & $21(36.8)$ & $33(41.2)$ & & \\
\hline Total & $23(100)$ & $57(100)$ & $80(100)$ & & \\
\hline
\end{tabular}

Table 3: Association between Duration with Occult HBV

\begin{tabular}{|l|c|c|c|c|}
\hline Variable & Occult HBV & No Occult HBV & Z test & P value \\
\hline Duration in Months (Median, IQR) & $4(3-6)$ & $6(3-12)$ & -1.361 & 0.174 \\
\hline
\end{tabular}

Table 4: Association between Blood Transfusion with Occult HBV

\begin{tabular}{|l|c|c|c|c|c|}
\hline $\begin{array}{l}\text { Blood } \\
\text { Transfusion }\end{array}$ & $\begin{array}{c}\text { Occult HBV } \\
\text { N (\%) }\end{array}$ & $\begin{array}{c}\text { No Occult HBV } \\
\text { N (\%) }\end{array}$ & $\begin{array}{c}\text { Total } \\
\text { N }(\%)\end{array}$ & $\begin{array}{c}\text { Chi-square } \\
\text { Test }\end{array}$ & P value \\
\cline { 1 - 4 } Yes & $22(95.7)$ & $50(87.7)$ & $72(90)$ & 1.15 & \multirow{2}{*}{0.28} \\
\hline No & $1(4.3)$ & $7(12.3)$ & $8(10)$ & & \\
\hline Total & $23(100)$ & $57(100)$ & $80(100)$ & & \\
\hline
\end{tabular}

Table 5: Association between ALT with Occult HBV

\begin{tabular}{|l|c|c|c|c|}
\hline ALT & $\begin{array}{c}\text { HBV Occult } \\
\text { N (\%) }\end{array}$ & $\begin{array}{c}\text { No Occult } \\
\text { N (\%) }\end{array}$ & $\begin{array}{c}\text { Total } \\
\text { N }(\%)\end{array}$ & \multirow{2}{*}{ P value } \\
\hline Significant Rise & $0(0)$ & $5(0)$ & $5(6.2)$ & \multirow{2}{*}{0.314} \\
\cline { 1 - 4 } No Significant Rise & $23(100)$ & $52(91.2)$ & $75(93.8)$ & \\
\hline Total & $23(100)$ & $57(100)$ & $80(100)$ & \\
\hline
\end{tabular}

Table 6: Association between Risk with Occult HBV

\begin{tabular}{|l|c|c|c|}
\hline Risk & Occult HBV N (\%) & No Occult HBV N (\%) & Total N (\%) \\
\hline Low & $3(13.0)$ & $2(3.5)$ & $5(6.2)$ \\
\hline Moderate & $5(21.7)$ & $16(26.1)$ & $21(26.2)$ \\
\hline High & $15(65.3)$ & $39(68.4)$ & $54(67.6)$ \\
\hline Total & $23(100)$ & $57(100)$ & $80(100)$ \\
\hline
\end{tabular}


Table 7: Association between various chemotherapeutic agents with Occult HBV

\begin{tabular}{|l|c|c|c|}
\hline Main drug & Occult HBV N (\%) & No Occult HBV N (\%) & Total N (\%) \\
\hline Adriamycin & $9(39.1)$ & $20(35.1)$ & $29(36.2)$ \\
\hline Bortezumab & $4(17.4)$ & $2(3.5)$ & $6(7.5)$ \\
\hline Cyclophosphamide & $1(4.3)$ & $2(3.5)$ & $3(3.8)$ \\
\hline Daunorubicin & $2(8.7)$ & $6(10.5)$ & $8(10)$ \\
\hline Dexamethasone & $1(4.3)$ & $4(7)$ & $5(6.2)$ \\
\hline Imatinib & $2(8.7)$ & $13(22.8)$ & $15(18.8)$ \\
\hline Rituximab & $4(17.4$ & $10(17.5)$ & $14(17.5)$ \\
\hline Total & $23(100)$ & $57(100)$ & $80(100)$ \\
\hline
\end{tabular}

Table 8: Prevalence of Occult $\mathrm{HBV} \&$ reactivation of $\mathrm{HBV}$

\begin{tabular}{|l|c|c|c|}
\hline Variable & Anti HBC +ve & HBV DNA +ve & HBV Reactivation \\
\hline Percent & $23(28 \%)$ & $5(6 \%)$ & $9(11 \%)$ \\
\hline
\end{tabular}

\section{Discussion}

This study highlights the importance of screening occult HBV infection in hematological malignancy before \& during chemotherapy. In OBI, HBV reactivation may be due to the disease process per se and autoimmunity ${ }^{(13,14)}$. The mortality rate of hepatitis in $\mathrm{HBV}$ reactivation is around 20 percent $^{12}$. Hence this study aimed at prevalence of occult $\mathrm{HBV} \&$ reactivation of $\mathrm{HBV}$ in hematological cancer patients before \& during chemotherapy in a tertiary care center which caters a quite large number of patients from the state

In our study the prevalence of occult HBV infection is $6 \%$ with isolated anti $\mathrm{HBC}$ positivity being $28 \%$. This is higher when compared to other studies $^{15,16}$. In a study by Sodhi et $\mathrm{al}^{17}$ the incidence of OBI was $1.9 \%$ (13 out of 690) which was less compared to our study. In a study by Yeo et $\mathrm{al}^{17}$ with study among 104lymphoma patients observed 46 patients out of 104 (44.2\%) were HBsAg negative/anti-HBc positive.

In an observational study of hematological cancer patients, Francisci et $\mathrm{al}^{19}$ reported the incidence of HBV reactivation was 18\%. In Egypt a study by Elkady et $\mathrm{al}^{20}$ showed that $18(34 \%)$ out of 53 HBsAg-negative patients with hematologic malignancies were found to be positive for antiHBc. Five of the $53(9.4 \%)$ patients with hematologic malignancies experienced HBV reactivation.

The reasons of the differences of several investigations for the occurrence of OBI could be due to geographical variations in prevalence of HBV, population characteristics, immunosuppressive conditions, HBV genotypes, study volume, unclear definition of OBI and also, the differences in the sensitivity of the techniques utilized for the identification of the HBV DNA, such as the PCR primer selection methods ${ }^{8}$.

In our study reactivation of $\mathrm{HBV}$ was $11 \%$ (9 out of 80) which was higher compared to other studies. In a study by Orhan et $a l^{21}$. in Turkey which included 1826 patients, 59 (3.2\%) cases were $\mathrm{HbSAg}$ positive and after chemotherapy, nine patients suffered from reactivation of Hepatitis B.A meta-analysis of 26 studies $^{22}$ reported that reactivation (in chronic $\mathrm{HBV}$, without prophylaxis) ranged from $4 \%$ to $68 \%$ (median, 25\%). Prophylaxis reduced the risk for HBV reactivation [odds ratio (OR): $0.12,95 \%$ confidence interval (CI) 0.06-0.22], HBV-related hepatitis (OR: $0.18,95 \%$ CI $0.10-0.32$ ) and chemotherapy interruption (OR: $0.10,95 \% \mathrm{CI}$ 0.04-0.27).

In our study there was no significant difference in $\mathrm{HBc}$ antibody positivity based on age, gender, duration of disease, previous blood transfusions (BT) or biochemical parameters (ALT) levels Occult HBV infection is transmitted through blood transfusion in cancer patients, except if the blood that is transfused is analyzed for anti-HB core antibody and HBV DNA ${ }^{(17,23)}$. Occult HBV infection is the largest cause of transfusiontransmitted HBV infection in many countries It is important to note that occult HBV patients 
may develop HBsAg seroreversion, with subsequent HBV reactivation after chemotherapy, particularly in the cases of serious immunosuppression, such as patients of hematopoietic stem- cell transplantation and also those patients getting rituximab-based chemotherapy $^{(24,25)}$

\section{Conclusions}

OBI is a significant challenge in clinical practice for specialists of different branches since the number of HBsAg-negative/anti-HBc-positive individuals (potential 'OBI carriers') is considerably higher than HBsAg-positive individuals worldwide. In our study the prevalence of occult HBV infection was $6 \%$ with isolated anti $\mathrm{HBC}$ positivity being $28 \%$. The issue of $\mathrm{HBV}$ reactivation in patients undergoing systemic chemotherapy for hematological malignancies is underreported in the medical literature. Reactivation of HBV occurred in $11 \%$ of patients in our study. The most common drugs implicated in HBV reactivation in our study for which the frequency of HBV reactivation appears to be highest are rituximab, anthracyclines, vincristine, cyclophosphamide, etoposide and imatinib. Life-threatening or severe hepatitis related to HBV reactivation have been reported. Chemotherapy withdrawal is sometimes required, which may affect the prognosis of cancer.

Limitations of our study were smaller sample size $\&$ less HBV DNA monitoring. Hence large prospective trials are needed to have a clear understanding of the situation. Therefore screening for occult hepatitis B with $\mathrm{HbsAg}$, total Anti $\mathrm{Hbc}$ and HBV DNA should be made mandatory before starting patients on immunosuppressants.

\section{References}

1. Lavanchy D. Hepatitis B virus epidemiology, disease burden, treatment, arid current and emerging prevention and control measures. Journal of Viral Hepatitis. 2004;11:97-107.
2. Liu Y, Li P, Li C, Zhou J, Wu C, Zhou YH. Detection of hepatitis B virus DNA among accepted blood donors in Nanjing, China. Virol J 2010; 7: 193.

3. Liu CJ, Kao JH. Global perspective on the natural history of chronic hepatitis B: role of hepatitis B virus genotypes a to j. Semin Liver Dis 2013; 33: 97-102.

4. Raimondo G, Navarra G, Mondello S, Costantino L, Colloredo G, Cucinotta E. Occult hepatitis B virus in liver tissue of individuals without hepatic disease. J Hepatol. 2008;48:743-6.

5. Perrillo RP. Acute ares in chronic hepatitis B: The natural and unnatural history of an immunologically mediated liver disease. Gastroenterology 2001;120:1009- 22.

6. Cheng JC, Liu MC, Tsai SY, Fang WT, Jer- Min Jian J, Sung JL. Unexpectedly frequent hepatitis $\mathrm{B}$ reactivation by chemoradiation in post gastrectomy patients. Cancer 2004;101:2126- 33.

7. Lau GK, Leung YH, Fong DY, Au WY, Kwong YL, Lie A, et al. High hepatitis B virus (HBV) DNA viral load as the most important risk factor for $\mathrm{HBV}$ reactivation in patients positive for $\mathrm{HBV}$ surface antigen undergoing autologous hematopoietic transplantation. Blood 2002; 99:2324- 30.

8. Torbenson M, Thomas D. Occult hepatitis B. Lancet Infect Dis. 2002;2:479-86.

9. Candotti D, Allain JP. Transfusiontransmitted hepatitis B virus infection. J Hepatol. 2009;51:798-809.

10. Lalazar G, Rund D, Shouval D. Screening, prevention and treatment of viral hepatitis B reactivation in patients with haematological malignancies. $\mathrm{Br} \mathrm{J}$ Haematol. 2007;136:699-712.

11. Yeo W, Chan PK, Hui P, Ho WM, Lam KC, Kwan WH, Zhong S, Johnson PJ. Hepatitis B virus reactivation in breast cancer patients receiving cytotoxic chemotherapy: a prospective study. J Med 
Virol. 2003;70:553-61.

12. Yeo W, Chan PKS, Ho WM, Zee B, Lam $\mathrm{KC}$, Lei $\mathrm{KI}$, et al. Lamivudine for the prevention of hepatitis B virus reactivation in hepatitis B s-antigen seropositive cancer patients undergoing cytotoxic chemotherapy. J ClinOncol 2004;22:927-34.

13. Lok AS, McMahon BJ. Chronic hepatitis B: update. Hepatology. 2009;50:661-2.

14. Yeo W, Johnson PJ. Diagnosis prevention and management of hepatitis B virus reactivation during anticancer therapy. Hepatology. 2006;43:209-20.

15. DeMitri, MS, Cassini R, Bernardi M. Hepatitis B virus-related hepatocarcinogenesis: molecular oncogenic potential of clear or occult infections. Eur J Cancer. 2010;46:2178-86.

16. Silva C, Goncales NS, Pereira JS, Escanhoela CA, Pavan MH, Goncales Jr FL. The in uence of occult infection with hepatitis B virus on liver histology and response to interferon treatment in chronic hepatitis $\mathrm{C}$ patients. Braz $\mathrm{J}$ Infect Dis. 2004;8:431-9.

17. Sodhi JS, Jeelani S, Geelani S. Occult hepatitis B virus infection as a cause of post transfusion hepatitis in patients with cancers. Indian J Gastroenterol. 2013;32: 297-301.

18. Yeo W, Chan TC, Leung NW, Lam WY, Mo FK, Chu MT, et al. Hepatitis B virus reactivation in lymphoma patients with prior resolved hepatitis B undergoing anticancer therapy with or without rituximab. J ClinOncol 2009;27:605-11.

19. Francisci D, Falcinelli F, Schiaroli E, Capponi M, Belfiori B, Cecchini E, et al. Reactivation of hepatitis $\mathrm{B}$ virus replication due to cytotoxic therapy: a five-year prospective study. Tumori 2012;98:220-4.

20. Elkady A, Aboulfotuh S, Ali EM, Sayed D, Abdel-Aziz NM, Ali AM, et al. Incidence and characteristics of $\mathrm{HBV}$ reactivation in hematological malignant patients in south Egypt. World J Gastroenterol 2013;19(37):6214-20.

21. Eren OO, Artac M, Boruban MC, Yavas $\mathrm{O}$, Arslan U, Basaranoglu M. Chemotherapy- induced Hepatitis B virus reactivation in $\mathrm{HbsAg}$ positive cancer patient: A single center experience. Med Oncol 2009;26:386- 92.

22. Paul S, Saxena A, Terrin N et al. Hepatitis $B$ virus reactivation and prophylaxis during solid tumor chemotherapy: a systematic review and meta-analysis. Ann Intern Med 2016; 164: 30-40.

23. Fong TL, Di Bisceglie AM, Gerber MA, Waggoner JG, Hoofnagle JH. Persistence of hepatitis B virus DNA in the liver after loss of HBsAg in chronic hepatitis B. Hepatology. 1993;18:1313-8.

24. Lalazar G, Rund D, Shouval D. Screening, prevention and treatment of viral hepatitis $\mathrm{B}$ reactivation in patients with haematological malignancies. $\mathrm{Br} \quad \mathrm{J}$ Haematol. 2007;136:699-712.

25. Onozawa M, Hashino S, Izumiyama K. Progressive disappearance of anti-hepatitis B surface antigen antibody and reverse seroconversion after allogeneic hematopoietic stem cell transplantation in patients with previous hepatitis B virus infection. Transplantation. 2005;79:61619. 